\title{
Karakteristik Taman Menteri Soepeno sebagai Taman Ramah Anak di Kota Semarang
}

\author{
Characteristic of Menteri Soepeno Park as Child Friendly Parks in \\ Semarang City
}

\author{
P. Prihantini ${ }^{\mathrm{a}}$, Wakhidah Kurniawati ${ }^{\mathrm{b}}$ \\ ${ }^{a}$ Universitas Semarang, Semarang, Indonesia \\ ${ }^{b}$ Universitas Diponegoro, Semarang Indonesia
}

\begin{abstract}
Abstrak
Kota layak anak merupakan sebuah kota yang memperhatikan dan mengakui adanya hak anak, termasuk penyediaan sarana bermain anak. Sarana perkotaan yang dapat mencerminkan pengakuan terhadap hak anak salah satunya adalah taman. Tujuan penelitian ini adalah untuk mengetahui karakteristik taman Menteri Seopeno sebagai taman ramah anak di Kota Semarang. Taman ini diharapkan dapat menjadi acuan bagi pengembangan taman ramah anak dalam mewujudkan kota yang layak anak. Metode yang digunakan dalam penelitian ini adalah kuantitatif dengan alat analisis skoring. Hasil penelitian menunjukkan bahwa taman Menteri Seopeno kurang ramah anak sehingga dibutuhkan beberapa pembenahan agar taman ini dapat menjadi salah satu sarana penunjang perwujudan kota layak anak di Semarang.
\end{abstract}

Kata kunci: taman, kota, layak anak

\begin{abstract}
The child-friendly city is a city that gives attention to and recognizes the existence of children's rights, including the provision of children's play facilities. Public facilities that can reflect recognition of children's rights are parks. The purpose of this study is to find out the characteristic of Menteri Soepeno park as a child-friendly park in Semarang city. This park is expected to be a reference for the development of child-friendly parks in realizing a child-friendly city. The method used in this research is quantitative with scoring analysis. The result showed that Menteri Soepeno park was not child-friendly, some improvements were needed so this park could be one of facility that supports the realization of a child-friendly city in Semarang.
\end{abstract}

Keyword: park, city, child-friendly

\section{Pendahuluan}

Kota Semarang telah mendapatkan penghargaan sebagai kota layak anak. Pengertian kota layak anak itu sendiri merupakan kota yang telah mengakui adanya hak anak, yang mengimplementasikannya dalam kebijakan termasuk dalam pembangunan kotanya. Kota layak anak dikembangkan untuk memastikan bahwa pemerintah kota secara konsisten membuat kebijakan yang terbaik untuk anak-anak seperti terpenuhinya hak anak seperti kesehatan, rasa aman, kepedulian, pendidikan non diskriminasi dan hidup di lingkungan yang berbudaya (Riggio, 2002)

Ketersediaan taman ramah merupakan salah satu indikator keseriusan pemerintah dalam mewujudkan sebuah kota yang layak anak. Ketersediaan taman tersebut harus diikuti ketepatan aktivitas yang berkembang serta akses yang terbuka untuk umum sehingga pengunjung tidak perlu membayar untuk dapat masuk ke area taman atau dikenal dengan istilah "pay for play" (Hart, 2002). Ruang publik terutama untuk anak seharusnya telah menjadi salah satu kebutuhan demi tercipta generasi yang baik, karena salah satu kebutuhan anak adalah ruang atau 
lingkungan yang sehat (Racelis \& Aguirre, 2002). Seto Mulyadi, seorang pemerhati anak pun mengemukakan dalam Majalah Ruang yang terbit tahun 2010 bahwa kota-kota di Indonesia kekurangan ruang publik dan seharusnya dapat dipenuhi setidaknya dengan menyisihkan minimal $1 \%$ dari lahan yang ada.

Ketersediaan taman bermain anak akan memberikan dampak positif bagi anak di masa dewasa, karena memori kolektif anak akan terekam hingga dewasa. Memori ini akan berpengaruh baik terhadap perkembangannya jika yang terekam dalam memorinya adalah hal baik seperti misalnya seorang anak akan lebih merasa senang bermain di tanah lapang dengan rerumputan yang alami karena akan memberikan anak kebebasan berekspresi (Lynch, 1960).

Belum adanya standar yang baku tentang ketersediaan taman ramah anak dan juga ketersediaan taman yang ada di sebagian besar kota di Indonesia hanya sebatas menyediakan ruang bermain saja tanpa memperhatikan efektivitas ketersediaanya. Penelitian ini bertujuan untuk mengetahui karakteristik taman Menteri Seopeno sebagai taman ramah anak di Kota Semarang

\section{Metode}

Penelitian ini diawali dari sebuah predikat kota layak anak di kota Semarang yang dianugerahkan oleh Kemeterian Pemberdayaan Perempuan dan Perlindungan Anak berdasarkan pada indikator yang telah ada. Berdasarkan fenomena yang terjadi penyusun menghimpun dasar teoritik untuk memperkuat temuan serta menyusun variabel oleh karenanya penelitian ini menggunakan pendekatan kuantitatif.

Ketersediaan taman aktif sangat diperlukan untuk arena bermain anak serta belajar dan bersosialisi. Taman Menteri Supeno sebagai salah satu taman yang memiliki potensi menjadi taman ramah anak merupakan salah satu langkah nyata dalam mewujudkan kota layak anak di Semarang. Penelitian ini bertujuan untuk mengkaji taman Menteri Soepeno Semarang yang berpotensi menjadi taman ramah anak. Kajian ini akan dilakukan dengan alat analisis scoring yaitu dengan cara memberikan nilai atau skor pada variabel yang telah tersusun sebelumnya.

Data merupakan tahapan dalam proses penelitian yang penting, karena hanya dengan mendapatkan data yang tepat maka proses penelitian akan berlangsung sampai peneliti mendapatkan jawaban dari perumusan masalah yang sudah ditetapkan (Sarwono, 2006).

Data yang digunakan dalam penelitian ini didominasi oleh data primer karena ketersediaan data sekunder yang mendukung penelitian ini sangat terbatas. Data primer diperoleh dari pengamatan langsung dan juga wawancara. Hasil dari pengamatan serta wawancara tersebut diolah untuk dapat menjadi data kuantitatif diskrit yaitu berupa angka yang bulat yang selanjutnya menjadi data nominal yaitu data angka yang merepresentasikan sesuatu obyek/jenis/karakter tertentu. Data hasil wawancara atau pun pengamatan langsung dapat dikuantitatifkan dengan cara memberikan kode misalnya angka 1 akan merepresetasikan rasa senang, angka 2 merepresentasikan kurang senang, serta angka 3 merepesentasikan tidak senang, dan seterusnya.

Tahapan selanjutnya yaitu analisis data yang merupakan tahapan penting sehingg harus dilakukan dengan teliti, dalam penelitian ini analisis yang dilakukan yaitu dengan menggunakan analisis semantik deferensial yaitu analisis yang digunakan untuk kajian dengan menggunakan skala tertentu dalam memilih konsep dengan menggunakan skor dari variabel-variabel (Sarwono, 2006). Analisis semantik deferensial ini dapat dilakukan dengan beberapa cara diantaranya dengan analisis jarak klaster dan analisis skor dari factor. Penelitian ini akan menggunakan analisis skor dari faktor, dimana skor atau nilai akan diberikan pada setiap indicator di masing-masing variabel.

Analisis ini menggunakan variable yang terbentuk dari beberapa kajian teori terkait taman ramah anak yang kemudian dianalisis dengan menggunakan skala Guttman. Skala Guttman memiliki beberapa ciri yaitu:

- Merupakan skala kumulatif, jika seseorang mengiyakan pertanyaan atau pertanyaan yang berbobot lebih berat, maka ia akan mengiyakan petanyaan atau pertanyaan yang kurang berbobot lainnya.

- Skala Guttman ingin mengukur satu dimensi saja dari suatu variabel yang multi dimensi sehingga skala ini bersifat unidimensional.

Berikut merupakan skala atau ukuran yang digunakan dalam penelitian ini. 
Tabel 1. Skala Pengukuran Variabel Penelitian (Analisis Penyusun, 2013)

\begin{tabular}{llr}
\hline \multicolumn{1}{c}{ Variabel } & \multicolumn{1}{c}{ Keterangan } & Skor \\
\hline - Ruang khusus & a. Tersedia & 3 \\
& b. Tidak tersedia & 1 \\
- Pembatasan & a. Ada & 3 \\
Akses & b. Tidak & 1 \\
- Ragam & a. Beragam & 3 \\
permainan & b. Terbatas & 1 \\
- Tingkat & a. Selalu menarik & 5 \\
Ketertarikan & b. Fluktuatif & 3 \\
Pengunjung & c. Tidak menarik & 1 \\
- Perlindungan & a. Tersedia & 3 \\
cuaca & b. Tidak & 1 \\
Skor Tertinggi & & 17 \\
Skor Terendah & & 5 \\
\hline
\end{tabular}

Berdasarkan hasil perhitungan menurut skor seperti pada table di atas maka akan diperoleh skor minimal sebesar 5 dan maksimal sebesar 17. Langkah selanjutnya adalah menentukan kesiapan taman Menteri Supeno sebagai taman ramah anak berdasarkan skor yang diperoleh. Perhitungan ini menggunakan rumus (Sturgess, 1926).

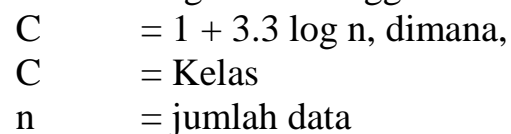

Selanjutnya setelah memperoleh jumlah kelas, maka ditentukan interval kelas, yaitu jarak masing-masing kelas, dengan rumus

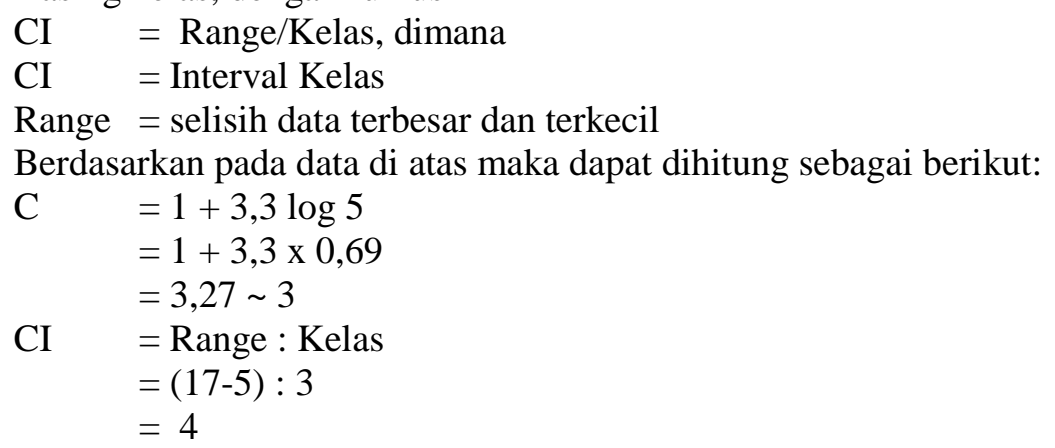

Berdasarkan perhitungan diatas maka diperoleh jumlah kelas sebanyak 4 dengan interval masing-masing kelas sebesar 3, adapun pembagian kelasnya adalah sebagai berikut:

Tabel 2 Kelas dan Interval (Analisis Penyusun, 2013)

\begin{tabular}{llll}
\hline Kelas & & Interval & \multicolumn{1}{c}{ Keterangan } \\
\hline I & $14-17$ & & Ramah Anak \\
II & $10-13$ & & Kurang Ramah Anak \\
III & $5-9$ & & Tidak Ramah Anak \\
\hline
\end{tabular}

Analisis karakteristik pengunjung akan menggunakan teori Rutledge (1981) A Visual Approach to Park Design yang mengungkapkan bahwa dalam menganalisis pengunjung sebuah kawasan dapat dilakukan dengan mengacu pada 5 hal yaitu What, Who, Where, When, dan Why. Kelima hal tersebut disusun dan di overlay sehingga dapat membentuk karakter pengunjung (Gambar 1).

Analisis yang kedua adalah analisis teritorialitas, analisis ini digunakan untuk mengetahui batasan dan ruang yang dapat dilihat dengan adanya penanda atau pembatas, hal ini digunakan untuk melihat batasan ruang dengan pengguna. Analisis selanjutnya adalah analisis frekuensi kunjungan, analisis ini melihat sejauh mana stimulus yang diberikan taman Menteri Soepeno terhadap pengunjung. Analisis ini dilakukan dengan melihat stimulus yang diterima pengunjung 
atau dari frekuensi kunjungan, semakin sering berkunjung akan berarti semakin bagus stimulus yang diberikan taman Menteri Soepeno terhadap pengunjung.

Gambar 2 dibawah ini akan menunjukkan perbandingan antara pengunjung dengan sarana yang tersedia atau keberagaman sarana permainan. Kondisi yang ideal seharusnya semua pengunjung dapat terakomodasi kebutuhannya sehingga pengunjung dapat merasa senang dan kemungkinan akan kembali lagi pada lain kesempatan. Hal ini juga dapat mempengaruhi frekuensi kunjungan, semakin baik taman Menteri Soepeno dalam mengakomodasi kebutuhan pengunjung makan semakin puas pengunjung dan frekuensi kunjungan pun dapat meningkat. Berdasarkan analisis tersebut maka dapat dihasilkan karakter pengunjung, zona yang sering dikunjungi yang terakit dengan teritorialitas serta frekuensi kunjungan berdasarkan pada stimulus yang diterima pengunjung.

$\begin{array}{lllll}\text { What } & \rightarrow & \text { Aktivitas } & \rightarrow & \text { POLA } \\ \text { Who } & \rightarrow & \text { Pengunjung } & \rightarrow & \text { KUNJUNGAN } \\ \text { Wherw } & \rightarrow & \text { Zona Kunjungan } & \rightarrow & \text { DAN } \\ \text { When } & \rightarrow & \text { Waktu } & \rightarrow & \text { KARAKTER } \\ \text { Why } & \rightarrow & \text { Alasan } & \rightarrow & \text { PENGUNJUNG }\end{array}$

Gambar 1. Analisis Karakteristik Pengunjung (Analisis Penyusun, 2013)

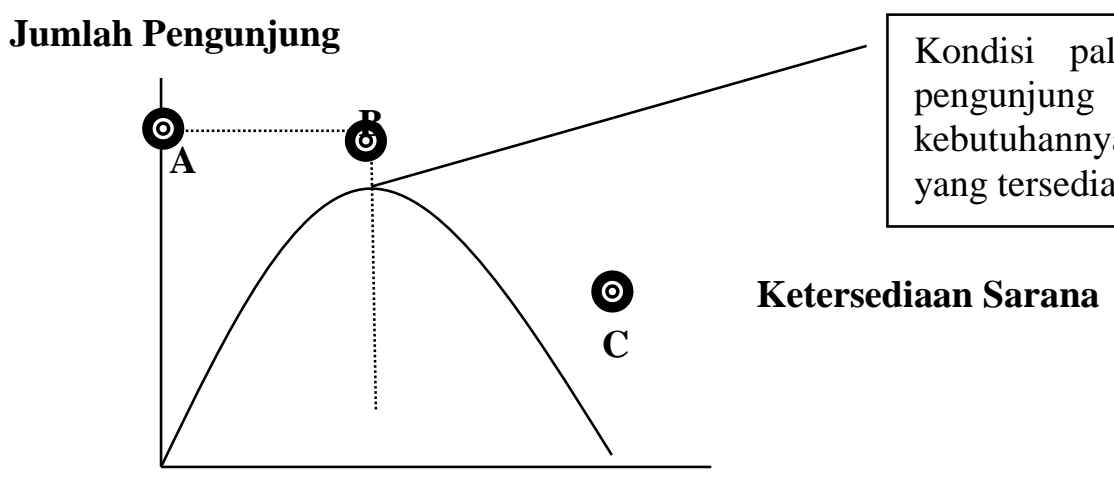

Gambar 2. Invitasi Taman Bermain di Taman Menteri Soepeno (Analisis Penyusun, 2013)

\section{Kajian literatur}

Anak-anak dalam perkembangannya membutuhkan kompetensi dengan bereksplorasi, bermain, berkesperimen dengan berbagai macam hal. Anak-anak harus memperluas jaringan sosial, pengetahuannya dengan didasarkan lingkungan rumah yang aman. Hal ini tentunya penting bagi pemerintah untuk menciptakan lingkungan fisik yang memungkinkan keluarga memberikan perhatian dan kesempatan untuk anak-anak bermain dengan bebas (Hart, 2002). Salah satu kebutuhan ruang untuk anak-anak yang sangat mutlah diperlukan adalah arena bermain, karena ruang atau arena bermain ini penting bagi perkembangan dan sosialisasi anak. Di beberapa kota terutama di Negara maju, dapat ditemukan begitu banyak ruang publik yang dapat digunakan oleh anak-anak untuk arena berkumpul dan bermain serta bersosialisasi dengan teman dan lingkungannya, namun hal ini kurang dapat dirasakan oleh anak-anak di beberapa negara terutama kelompok negara berkembang.

Keterbatasan akses terhadap fasilitas yang mengakibatkan kurangnya sosialisasi anak terhadap lingkungan sekitar akan berdampak kepada perkembangan anak yang kurang optimal. Anak-anak membutuhkan ruang untuk berkumpul dengan teman dan lingkungannya untuk belajar, megekspresikan diri dan bersosialisasi yang berguna bagi perkembangannya. Taman maupun arena bermain saat ini lebih mengutamakan unsur bisnis dan kurang menjawab pemenuhan kebutuhan anak. Pemerintah sudah selayaknya memenuhi kebutuhan taman atau ruang bermain tersebut, karena pada saat anak bermain adalah proses belajar, dan dalam proses belajar tersebut anak-anak mengasah potensi-potensi kecerdasan. Langkah nyata yang harus disediakan oleh sebuah kota adalah menyediakan ruang bermain minimal 5\% dari total luas wilayahnya. Kondisi saat ini di sebagian besar kota di Indonesia termasuk Semarang masih 
minim ruang publik untuk anak-anak, $1 \%$ saja mungkin tidak ada (Redaksi dan Mulyadi, 2010).

Pemberian perhatian pada ruang-rang sementara yang komplek dapat megungkapkan beberapa pemandangan bentuk koneksi dalam keseharian hidup. Koneksi ini meliputi hubungan antara masa lalu, masa kini, antara anak, kelarga, komunitas dan bangsa serta antara perbedaan tempat (Moss, 2010). Berdasarkan hal tersebut maka sangatlah penting memberikan perhatian kepada anak-anak, karena seorang anak memiliki memori kolektif yang terbawa sampai pada masa dewasanya sehingga sangatlah penting seorang anak berada dalam lingkungan yang harmonis dan dalam pengasuhan yang benar untuk memberikan memori kolektif dan bekal masa dewasa yang bagus.

Penyedian ruang bagi anak yang memenuhi kebutuhan anak serta desain yang sesuai dengan anak akan dapat memberikan kesan positif bagi anak. Memori anak sangatlah kuat yang terbawa hingga dewasa. Hal ini seperti yang diungkapkan oleh Moss, (2010) bahwa ada hubungan antara masa lalu, masa kini, antara anak, keluarga, komunitas dan bangsa serta antara perbedaan tempat. Hal senada juga pernah dilakukan dalam penleitian yang menyatakan seseorang anak yang pernah mengalami pelecehan seksual pada masa kecil yang misalnya terjadi pada sebuah ruangan, maka hal tersebut akan terekam dalam memoriya hingga dewasa (Reavey, 2010). Pentingnya menciptakan suatu ruang yang ramah terhadap anak agar dapat tercipta kesan dan memori yang baik, untuk masa depan yang baik. Berdasarkan hasil penelitian bahwa terdapat hubungan yang erat antara anak-anak, kota dan lignkungannya termasuk dampak pada pengembangan mental, kemandirian dan interaksi serta persepsi terhadap lingkungan di sekitarnya (Glesson \& Sipe, 2006).

Ruang yang dapat digunakan bagi perkembangan anak ini tidak harus berupa ruang terbuka, namun dapat pula pada ruang tertutup namn yang bersifat publik, meskipun sebagian besar ruang public didominsai dengan ruang terbuka. Ruang terbuka dan tertutup mempunyai karakteristik yang berbeda dalam beberapa aspek seperti diantaranya yang terlihat pada tabel 3 berikut.

Tabel 3. Karakteristik Ruang Terbuka dan Tertutup (Malone, 2002; Sibley, 2002)

\begin{tabular}{|c|c|c|}
\hline Karakteristik & Ruang terbuka & Ruang tertutup \\
\hline Pengertian batasan & Batasan ruang kurang jelas & Batasan ruang sangat jelas \\
\hline Sistem nilai & Multiple & Dominan \\
\hline $\begin{array}{l}\text { Respon terhadap perbedaan } \\
\text { dan keberagaman }\end{array}$ & Diperbolehkan & Tidak diloteransi \\
\hline Aturan kebijakan & Tidak terlalu diperlukan & $\begin{array}{l}\text { Batasan pengelolaan dan } \\
\text { pengaturan kebijakan yang ketat }\end{array}$ \\
\hline Posisi public & Marginal & Centre \\
\hline Sudut pandang budaya & Multicultural & Monokultural \\
\hline
\end{tabular}

\section{Taman Bermain Anak}

Taman bermain anak merupakan salah satu bagian dari taman kota dengan fungsi ekologis, rekreatif, estetis, dan sebagian ada juga yang memiliki fungsi seagai sarana olahraga (Dirjen Penataan ruang, 2006). Taman kota juga dapat diartikan sebagai sebuah taman yang berfungsi sebagai tempat bertemunya masyarakat dari semua kelas sosial. Taman merupakan ruang terbuka yang muncul dari adanya sejarah masa lalu yang memiliki tata kota yang didalamnya terdapat lokasi pusat yang berfungsi sebagai penanda suatu kota atau pun kawasan (Cynthia, 1994).

Taman bermain merupakan salah satu sarana yang dibutuhkan anak-anak sebagai tempat berkumpul, bermain dan bersosialisasi dengan yang lain. Proses ini sangat penting sehingga kebutuhan taman bermain pun menjadi sangat dibutuhkan. Kondisi yang terjadi saat ini seringkali taman bermain menjadi komersial dan tak jarang yang berbayar sehingga tidak semua lapisan masyarakat dapat mengaksesnya.

Taman kota yang ramah anak masih sangat jarang terutama di beberapa kota besar di Indonesia termasuk di Semarang. Taman aktif yang tersedia masih sangat jarang menyediakan sarana bermain untuk anak. Beberapa alasan termasuk biaya perawatan maupun pengadaan yang cukup mahal sehingga taman-taman yang tersedia hanya sekedarnya dalam menyediakan sarana permainan. Pengelolaan taman bermain dapat dilakukan dengan beberapa model diantaranya model publik (public), model kerjasama publik swasta (public/privat conventure) dan model 
orientasi pasar (market oriented civic mode). Ketiga model tersebut mempunyai keuntungan dan kelemahan sehingga dapat diperbandingkan sebagai model yang dapat diterapkan di taman bermain. Perbandingan antara ketiga model tersebut dapat dilihat pada tabel 4.

Tabel 4 Model Pengelolaan Taman Kota (Garvin, Berens, \& Leinberger, 1997)

\begin{tabular}{|c|c|c|}
\hline Model & Keuntungan & Kelemahan \\
\hline Public & $\begin{array}{l}\text { - Pendanaan berasal dari } \\
\text { pemerintah } \\
\text { - Pelayanan dasar dilakukan oleh } \\
\text { pemerintah } \\
\text { - Focus pada pemenuhan } \\
\text { kebutuhan } \\
\text { - Terdapat sejarah panjang yang } \\
\text { mempertemukan antara ruang } \\
\text { public dan taman } \\
\text { - Biasanya mampu menjangkau } \\
\text { masyarakat dalam skala besar } \\
\text { - Terbuka untuk masyarakat umum } \\
\text { dan pelaku bisnis dalam ususlan } \\
\text { desainnya }\end{array}$ & $\begin{array}{l}\text { - Masyarakat meragukan } \\
\text { kemampuan pemerintah dalam } \\
\text { manajemen taman } \\
\text { - Manajemen kurang efektif karena } \\
\text { pemerintah mengurusi banyak } \\
\text { taman } \\
\text { - Kurang kreatif dibandingkan } \\
\text { swasta } \\
\text { - Keputusan-keputusan yang diambil } \\
\text { dipengaruhi oleh kepentingan } \\
\text { khusus } \\
\text { - Pendanaan diperolah dari pajak } \\
\text { - Kemungkinan dapat dilimpahkan } \\
\text { ke swasta terutama pada saat } \\
\text { kekurangan dana }\end{array}$ \\
\hline $\begin{array}{c}\text { Public/Privat } \\
\text { Conventur }\end{array}$ & $\begin{array}{l}\text { - Sesuai dengan kebutuhan pasar } \\
\text { - Pengguna dapat menaikkan } \\
\text { modal dengan bebas } \\
\text { - Kerjasama dapat dilakukan } \\
\text { dengan memberikan pelayanan } \\
\text { dari sebagian kecil taman saja. }\end{array}$ & $\begin{array}{l}\text { - Pelayanan tidak dilakukan oleh } \\
\text { pemerintah jika pengguna } \\
\text { dikenakan biaya } \\
\text { - Kerjasama dapat diperpanjang } \\
\text { waktunya sehingga dikhawatirkan } \\
\text { dapat mengubah tatanan } \\
\text { lingkungan } \\
\text { - Dalam jangka waktu lama } \\
\text { dikhawatirkan pihak swasta } \\
\text { antusias untuk lebih menguasai }\end{array}$ \\
\hline $\begin{array}{c}\text { Market Oriented } \\
\text { Civic }\end{array}$ & $\begin{array}{l}\text { - Sesuai dengan kebutuhan pasar } \\
\text { - Pengguna dikenakan biaya yang } \\
\text { dapat menaikkan pendapatan } \\
\text { pemerintah } \\
\text { - Berada di kawasan dengan harga } \\
\text { tanah tinggi jika modal besar } \\
\text { - Berada di kawasan dengan harga } \\
\text { tanah rendah jika modal kecil } \\
\text { - Dapat memberikan peningkatan } \\
\text { dan perawatan pada taman } \\
\text { dengan memberikan pelayanan } \\
\text { tingkat tinggi }\end{array}$ & $\begin{array}{l}\text { - Dukungan peningkatan kota dapat } \\
\text { dilakukan bahkan pada lahan yang } \\
\text { bernilai tinggi } \\
\text { - Kemungkinan manajemen tidak } \\
\text { stabil pada daerah lahan bernilai } \\
\text { rendah } \\
\text { - Pihak swasta dapat merasa } \\
\text { memiliki kekuatan lebih. }\end{array}$ \\
\hline
\end{tabular}

Pengelolaan taman bermain akan mempengaruhi kualitas dari taman tersebut baik penyediaan sarananya maupun pelayanan terhadap para pengguna. Taman bermain seharusnya dapat melayani dan djangkau semua lapisan. Taman bermain yang ideal dikemukakan oleh Redaksi dan Mulyadi (2010) yaitu sebuah tempat lapang dengan udara yang segar yang bersifat alamiah dengan ayunan dan panjatan dari kayu yang akan memberikan kegembiraan dan tantangan pada anak-anak. Penyediaan taman bermain yang ideal masih sangat jarang ada di kota-kota besar di Indonesia terkait permasalahan pendanaan maupun perawatan. Beberapa kriteria untuk sebuah taman bermain yang ideal menurut Walsh dalam Glesson dan Sipe (2006) adalah, sebagai berikut:

a. Deliniasi ruang khusus untuk anak-anak

b. Akses, adanya pembatasan akses untuk memasuki area taman bermain jadi hanya diperuntukan bagi anak-anak dengan batasan usia tertentu

c. Ragam, permainan yang disediakan sebaiknya beragam agar anak-anak tidak bosan dan memiliki pilihan untuk bermain

d. Invitasi, tingkat stimulasi yang diterima oleh pengguna harus diperhatikan 
e. Perlindungan cuaca, tempat bermain hendaknya memperhitungkan adanya perubahan cuaca seperti adanya tempat berteduh pada saat hujan

\section{Ruang dan Aktivitas}

Ruang merupakan salah satu tempat berekpresi sehingga penting untuk anak-anak memiliki ruang yang dapat digunakan untuk mengekspresikan diri serta bersosialisasi dengan yang lain. Taman bermain anak, taman rekreasi dan sejenisnya telah ada di beberapa kota maupun tingkat kawasan yang lebih kecil, namun tidak kesemuanya mampu menarik minat anak, atau pun aktivitas yang sesuai dengan peruntukannya. (Lawson, 2007) mengemukakan bahwa sebuah ruang bisa menjadi lebih bermakna jika ruang tersebut memiliki bahasa yang mampu dicerna dengan baik oleh penggunanya. Manusia memiliki bahasa untuk berbicara begitu pula sebuah ruang juga memiliki bahasa yang ingin disampaikan kepada penggunanya, oleh karenanya terdapat hal-hal yang perlu diperhatikan dalam menciptakan ruang maupun lingkungan perkotaan.

Tiga hal penting yang dapat lebih memberikan makna bagi suatu ruang atau lingkungan yaitu keamanan, stimulasi, dan identitas. Stimulasi dalam hal ini yaitu sebuah ruang yang diciptakan, misal untuk anak-anak tentunya ruang atau lingkungan tersebut memiliki warna, memiliki gaya yang mencerminkan dunia anak-anak sehingga anak-anak tertarik untuk berada didalamnya. Stimulasi yang diberikan kepada sebuah ruang pun akan mempengaruhi aktivitas yang ada di dalamnya, jika stimulasi kurang kuat akan menimbulkan kebosanan, sedangkan jika terlalu kuat justru menimbulkan tekanan yang kurang menguntungkan.

Hal selanjutnya yaitu keamanan, terkait dengan ruang anak tentunya sebuah lingkungan maupun ruang bagi anak harus memiliki standar keamanan yang disesuaikan dengan anak-anak agar anak-anak merasa nyaman dan orang tua merasa aman untuk mengijinkan anaknya berada dalam sebuah lingkungan atau ruang tersebut, dan selanjutnya adalah identitas. Sebuah lingkungan maupun ruang harus memiliki identitas yang jelas untuk meyakinkan penggunanya bahwa mereka tidak berada dalam tempat yang salah, identitas ini dapat dibentuk atau terbentuk sendiri dari sudut pandang pengguna berdasarkan pengamatannya.

Ruang dan aktivitasnya dapat juga dilihat dari bentuk ruang tersebut, tak jarang banyak ruang yang memiliki bentuk unik namun kemudian justru kurang mampu menciptakan aktivitas yang diharapkan. Pemahaman kebutuhan dasar manusia dengan hubungan antara perancangan dan perilaku manusia sangat diperlukan dalam menciptakan sebuah ruang yang tepat guna (Laurens, 2004).

Respon seseorang terhadap lingkungan maupun ruang bergantug kepada individu yang bersangkutan dalam mempersepsikan ruang, begitu halnya dengan ruang public yang melayani kepentingan social. Perilaku sosial dalam lingkungan dapat diamati dari fenomena perilaku terhadap lingkungan, kelompok-kelompok pengguna, serta tempat atau ruang terjadinya aktivitas. Perilaku manusia terhadap lingkungan akan dipengaruhi oleh beberapa hal diantaranya ruang personal, teritorialitas, kesesakan dan kepadatan, serta privasi.

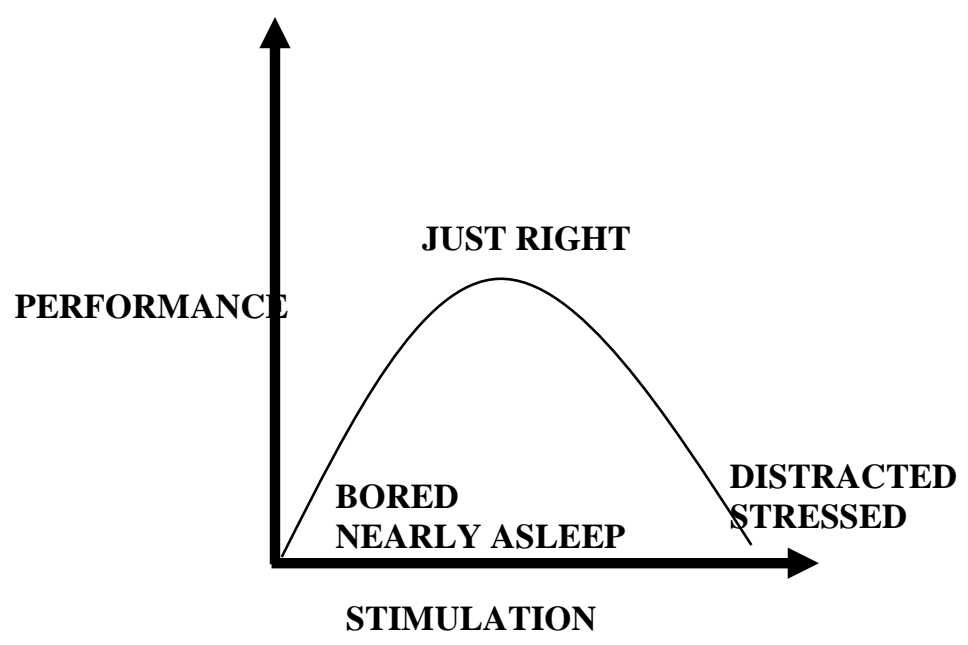

Gambar 3 Grafik Stimulasi (Lawson, 2001) 
Ruang personal merupakan domain kecil sejauh jangkauan manusia yang dimiliki oleh setiap orang. Besarnya ruang personal itu bergantung kepada dengan siapa kita sedang berhadapan, atau dengan kata lain ruang personal adalah suatu jarak komunikasi sehingga dalam kepentingan keamanan atau pengendalian maka seorang manusia mengatur jarak personalnya dengan pihak lain. Ruang personal dipengaruhi oleh beberapa factor diantaranya factor personal yaitu jenis kelamin, umur, tipe kepribadian serta latar belakang budaya. Faktor lain yang juga mempengaruhi besarnya ruang personal yaitu factor situasi lingkungan serta factor budaya dan variasi etnis (Laurens, 2004).

Teritorilitas adalah kecenderungan untuk menguasai daerah yang lebih luas bagi pengguna oleh seseorang atau sekelompok pengguna atau bagi fungsi tertentu. (Edney, 1974; Laurens, 2004) mendifiniskan teritorialitas sebagai sesuatu yang berkaitan dengan ruang fisik, tanda kepemilikan, pertahanan, penggunaan yang eksklusif, personalisasi dan dentitas, termasuk didalamnya dominasi, control, konflik, kemananan, gugatan akan sesuatu dan pertahanan. Teritorialitas dapat diklasifikasikan menjadi tiga seperti yang dikemukakan oleh Atman (1980) dalam Laurens (2004), yaitu teritori primer, teritori sekunder, teritori public. Teritori primer adalah tempat-tempat yang sangat pribadi sifatnya, hanya boleh dimasuki oleh orang-orang yang sudah sangat akrab atau yang sudah mendapatkan izin khusus. Teritori sekunder adalah tempat yang dimiliki bersama oleh sejumlah orang yang sudah cukup saling mengenal, sedangkan teritori publik adalah tempat-tempat yang terbuka untuk umum. Teritorialitas berfungsi sebagai proses sentral dalam personalisasi, agresi, dominasi, menenangkan, koordinasi dan kontrol. Personalisasi dan penandaan dapat dilakukan dengan memberi nama, tanda atau menempatkan pada lokasi yang strategis, bisa terjadi tanpa kesadaran akan teritorialitas. Salah satu fungsi teritorialitas ini adalah sebagai control agar tidak terjadi kondisi sesak atau padat. Kesesakan dan kepadatan adalah keadaan apabila ruang fisik yang tersedia sangat terbatas dibandingkan dengan jumlah penggunanya. Privasi adalah usaha untuk mengoptimalkan pemenuhan kebutuhan social manusia.

\section{Hasil dan Pembahasan}

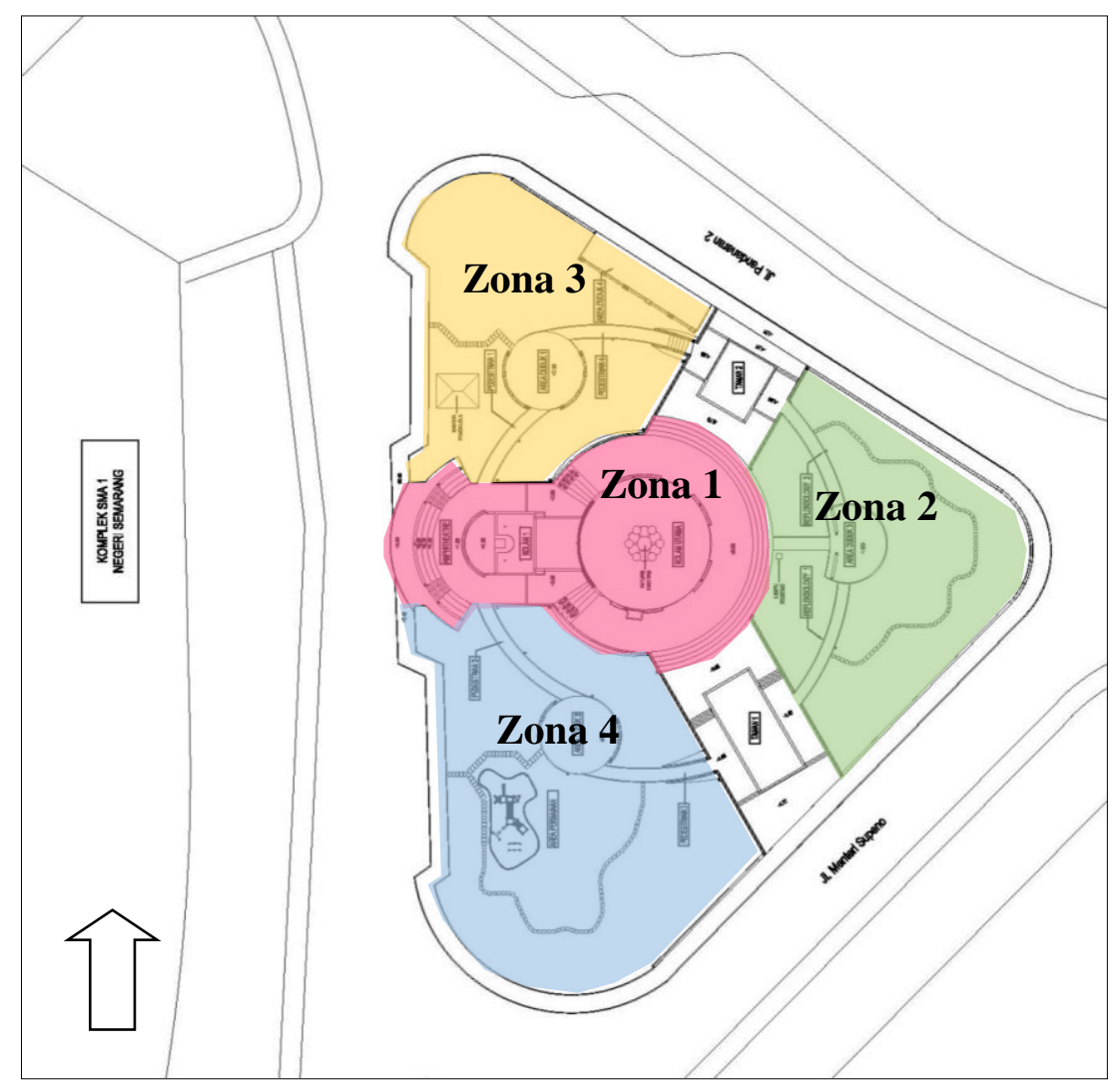

Gambar 4. Pembagian Zona pada Taman Menteri Soepeno (Olahan dan Dinas Kebersihan dan Pertamanan Kota Semarang, 2009) 
Taman Menteri Soepeno merupakan taman yang cukup luas dengan berbagai fasilitas serta kemudahan pencapaian dari sudut kota Semarang di bagian manapun. Taman ini menjadi tempat penganugerahan kota layak anak yang pertama kali yaitu pada tahun 2012 yang lalu. Taman Menteri Soepeno telah berubah nama menjadi taman Indonesia Kaya dengan penataan yang tidak banyak berubah seperti pada gambar 4 di atas ini. Tahapan analisis ini akan membagi taman Menteri Soepeno menjadi 4 zona dan dari teori Walsh dalam Glesson dan Sipe yang kemudian didukung dengan teori lainnya maka variabel yang terbentuk yaitu ketersediaan taman bermain, batasan pengguna, ragam permainan, tingkat ketertarikan pengunjung, serta fasilitas perlindungan cuaca. Kelima variabel tersebut akan dianalis dalam tiga analisis yaitu analisis ketersediaan taman bermain dan batasan pengguna, analisis ragam permainan dan tingkat ketertarikan pengunjung, dan yang terakhir analisis fasilitas perlindungan cuaca.

\section{Ketersediaan Taman Bermain dan Batasan Pengguna}

Ketersediaan ruang khusus bagi anak di Taman Menteri Soepeno telah terwadahi dengan adanya arena permainan yang tersedia di areal taman. Ketersediaan ruang bermain ini dilengkapi dengan beberapa sarana bermain seperti ayunan, perosotan, jungkat-jungkit dan yang lainnya. Sarana bermain yang telah tersedia sudah cukup mampu mewadadi aktivitas pengunjung terutama anak-anak, namun beberapa hal terkait deliniasi atau pembatasan akses kepada areal bermain tersebut kurang diperhatikan.

Areal bermain yang tersedia di taman ini tidak memiliki batasan fisik berupa pagar atau pemisah antara ruang yang lain sehingga setiap pengunjung dapat leluasa mengakses areal bermain ini. Batasan non fisik berupa peraturan atau target pengguna yang diharapkan pun tidak ditemukan di areal ini sehingga siapa pun dapat menggunakan areal bermain ini. Hal ini sering dilupakan oleh para perancang kawasan maupun kota bahwa faktor pengguna memiliki peran penting dalam mendukung berjalannya fungsi dari kawasan tersebut. Perancangan sebuah kawasan masih kurang fokus kepada target pengguna atau kepuasan pengguna, namun lebih fokus kepada keindahan rancangannya (Laurens, 2004). Masyarakat belum mampu dengan sendirinya memahami target pengguna yang seharusnya oleh karenanya perancang harusnya tanggap terhadap keadaan ini, dengan kata lain rancangan sebuah kawasan harus tanggap dengan kondisi sosial yang berkembang.

Respon seseorang terhadap lingkungannya bergantung kepada bagaimana individu tersebut mempersepsikan lingkungannya (Laurens, 2004). Hal ini sangat jelas terlihat pada areal bermain anak-anak yang ada di Taman Menteri Soepeno yang tidak memiliki batasan secara fisik maupun non fisik, sehingga masyarakat dapat mempersepsikan bahwa areal tersebut memiliki akses terbuka bagi setiap pengunjung.

Kondisi areal bermain yang tanpa dilengkapi batasan secara fisik maupun non fisik ini mengakibatkan beberapa hal diantaranya sarana permainan cepat rusak karena kapasitas yang berlebih, selain itu tidak adanya prioritas pengguna mengakibatkan kesempatan anak terbatas atau terhalangi oleh pengguna lain yang justru diluar dari batasan usia anak.

Area bermain akan bertambah pada hari Minggu pagi karena adanya pasar mingguan yang juga menyediakan area permainan. Zona 2 merupakan tempat digelarnya area permainan tersebut dengan pengawasan langsung dari penyelenggara menjadikan taman ini memiliki batasan pengguna yang ditentukan oleh pihak penyelenggara. Area bermain ini hanya diperuntukkan untuk anak-anak dan dengan tegas pihak penyelenggara memberikan batasan sehingga target pengguna cukup tepat sasaran.

Tabel 4. Analisis Ketersedian dan Batasan Pengguna Taman Bermain (Analisis Penyusun, 2013)

\begin{tabular}{llllll}
\hline \multicolumn{5}{l}{ Ketersediaan dan Batasan Pengguna Taman Bermain dari Teori dan Eksisting } \\
\hline Teori & Taman yang ideal akan & Lawson & $(2001)$ & Respon seseorang & terhadap \\
& menyediakan ruang & mengemukakan bahwa & lingkungannya bergantung kepada \\
bermain khusus dengan & sebuah ruang bisa bagaimana individu tersebut \\
batasan pengguna yang & menjadi lebih bermakna & mempersepsikan & lingkungannya \\
jelas, Walsh dalam & jika ruang tersebut & (Laurens, 2004) \\
Glesson dan Sipe (2006) & memiliki bahasa yang \\
& mampu dicerna dengan \\
& baik oleh penggunanya
\end{tabular}




\begin{tabular}{|c|c|c|c|}
\hline \multicolumn{4}{|c|}{ Ketersediaan dan Batasan Pengguna Taman Bermain dari Teori dan Eksisting } \\
\hline $\begin{array}{c}\text { Zona } \\
4\end{array}$ & $\begin{array}{l}\text { Tidak memiliki batasan } \\
\text { pengguna jelas baik } \\
\text { secara fisik maupun non } \\
\text { fisik }\end{array}$ & $\begin{array}{l}\text { Ketersediaan } r \text { menjadi } \\
\text { kurang terasa karena } \\
\text { banyak pencampuran } \\
\text { pengguna }\end{array}$ & $\begin{array}{l}\text { Ruang bermain dapat diakses oleh } \\
\text { siapapun, yang menyebabkan kurang } \\
\text { tepat guna karena digunakan tidak } \\
\text { hanya anak-anak namun juga orang } \\
\text { dewasa }\end{array}$ \\
\hline $\begin{array}{c}\text { Zona } \\
2\end{array}$ & $\begin{array}{l}\text { Batasan pengguna } \\
\text { ditentukan oleh pihak } \\
\text { penyelenggara } \\
\text { permainan }\end{array}$ & $\begin{array}{l}\text { Suasana area bermain } \\
\text { sangat kental karena } \\
\text { hanya anak-anak saja } \\
\text { yang dapat mengakses } \\
\text { sarana ini. }\end{array}$ & $\begin{array}{l}\text { Batasan ini tetap disambut positif } \\
\text { oleh pengunjung sehingga yang } \\
\text { menggunakan sarana permainan } \\
\text { adalah anak-anak dan orang tua } \\
\text { hanya mengawasi. }\end{array}$ \\
\hline
\end{tabular}

Taman bermain anak tidak hanya dilihat berdasarkan ketersediaan saja, namun batasan pengguna cukup penting untuk diperhatikan agar ruang yang tersedia tepat guna.

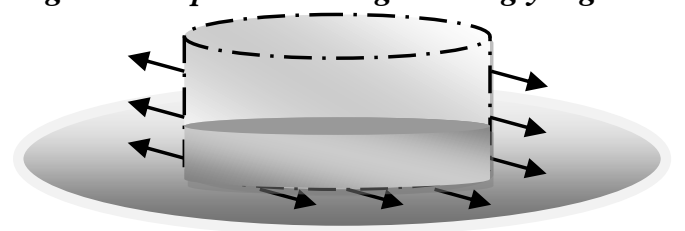

Ilustrasi Kondisi Taman Bermain di Taman Menteri Soepeno

Tidak adanya batasan tersebut mengakibatkan celah yang memungkin siapa saja menggunakan areal bermain yang pada mulanya ditujukan untuk anak-anak. Kebocoran tersebut bisa menjadikan fungsi areal bermain berkurang, target pengguna menjadi kurang fokus kepada anak-anak sehingga sarana permainan yang tersedia pun tidak optimal mewadahi aktifitas bermain anak dan bahkan cenderung menjadi lebih cepat rusak karena kelebihan kapasitas. Regulasi serta zonasi yang jelas sangat diperlukan untuk mengatasi kebocoran ini.

\section{Ragam Permainan dan Invitasi Taman Menteri Soepeno}

Taman yang ramah anak tidak hanya bisa dilihat dari ketersediaan arena bermain anak saja, namun bahan dari sarana permainan, kondisi lingkungan permainan juga dapat menstimulasi anak-anak untuk merasa senang atau sebaliknya. Menurut Lynch (1960), anakanak akan sangat lekat pada sebuah tempat bermain dengan permukaan rumput, dimana mereka bebas berlari dan berekspresi, hal ini juga diperkuat oleh pernyataan dari pakar anak-anak yang menyatakan bahwa taman terbuka yang hijau dengan udara yang segar akan dapat membantu perkembangan anak (Mulyadi, 2010).

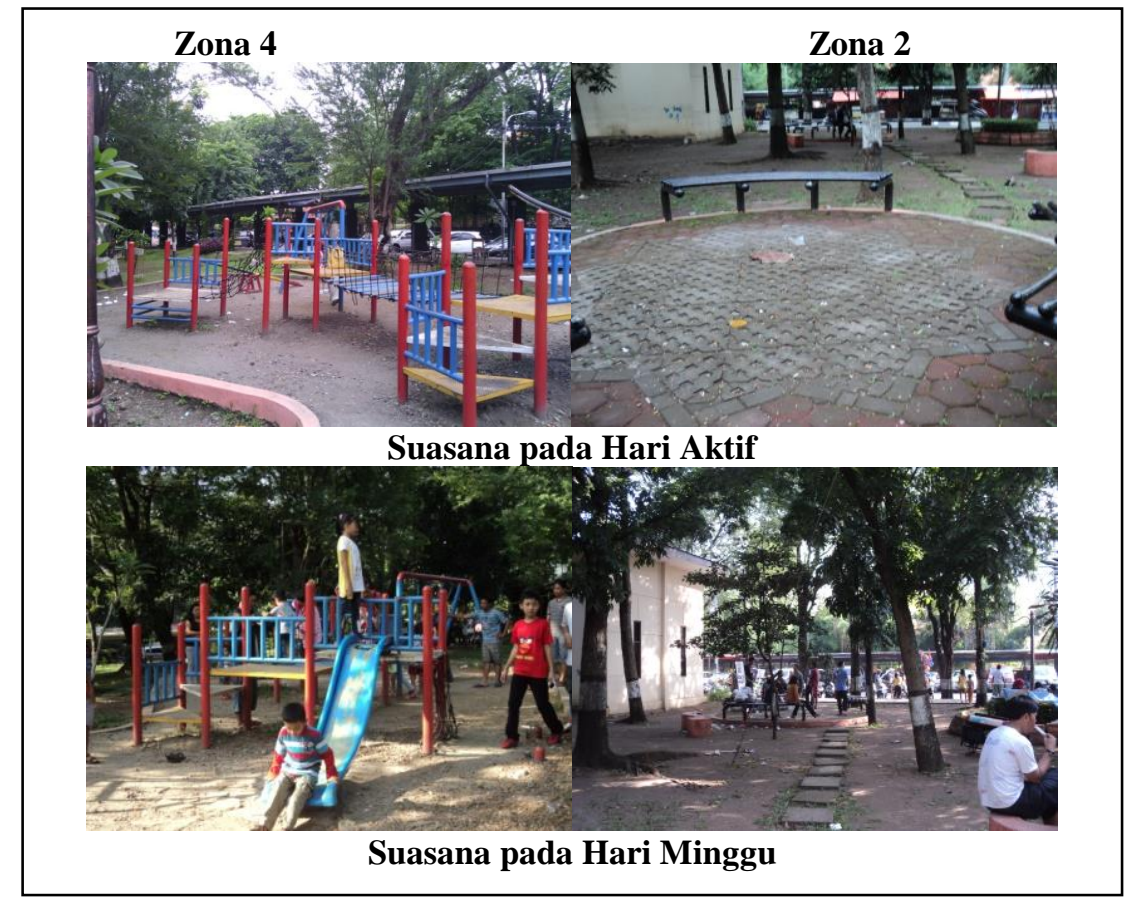

Gambar 5 . Suasana Area Bermain Anak pada Zona 4 (Taman Permanen) dan Zona 2 (Taman Mingguan) (Dokumentasi Penulis, 2013) 
Ragam permainan cukup memberikan pengaruh kepada daya tarik taman untuk dikunjungi. Taman bermain yang tersedia di taman Menteri Soepeno ini memiliki jenis permainan yang beragam mulai dari ayunan, perosotan, jungkat jungkit hingga jembatan gantung. Tambahan area bermain terjadi pada hari minggu yaitu di zona 2 berupa arena permainan seperti kereta putar, istana balon serta delman yang disediakan oleh penyelenggara. Keberadaan area permainan tambahan ini menjadi alternative pilihan bagi pengunjung taman Menteri Soepeno. Kegiatan ini menambah minat kunjungan terutama anak-anak di hari libur, sekaligus menambah kuatnya potensi daya tarik taman sebagai taman yang mampu mewadahi aktivitas bermain anak.

Ragam permainan yang tersedia di taman Menteri Soepeno berpengaruh terhadap invitasi atau daya tarik yang mampu mempengaruhi anak-anak berkunjung di taman ini. Hal ini mengindikasikan bahwa ragam permainan secara langsung mempengaruhi daya tarik dan jumlah kunjungan. Semakin beragam permainan yang disediakan semakin tinggi pula daya tarik taman atau disebut dengan invitasi serta berdampak pada jumlah kunjungan yang juga melonjak.

Invitasi taman Menteri Soepeno selain dari ragam permainan yang tersedia juga dari aksesibilitas atau kemudahan pencapaian. Lokasi yang strategis berada di pusat kota juga menjadi daya tarik tersendiri bagi pengunjung. Karakteristik taman Menteri Soepeno yang terus berkembang dengan kelengkapan sarana yang semakin baik menjadi daya tarik tersendiri. Karakteristik pengunjung pun menjadi beragam dari anak-anak hingga orang dewasa. Kebutuhan pengunjung akan sebuah telah dapat terpenuhi dari mulai anak-anak hingga orang tua. Sarana taman bermain merupakan sarana yang disediakan khusus untuk anak-anak, area skatepark merupakan sarana yang diperuntukkan untuk anak muda yang memiliki hobi bermain skateboard. Pengunjung dalam kelompok orang tua juga diberikan sarana yaitu berupa jalur refleksiologi untuk olahraga ringan. Kelengkapan sarana yang tersedia tersebut sudah merupakan daya tarik yang cukup kuat untuk menarik minat pengunjung.

Kelengkapan sarana yang tersedia merupakan daya tarik terbesar bagi pengunjung. Taman ini diperuntukkan untuk segala usia dari anak-anak hingga dewasa bahkan lanjut usia. Daya tarik yang begitu besar tersebut menjadikan taman ini sering dikunjungi pada hari aktif maupun hari libur atau hari Minggu. Puncak kunjungan terjadi pada hari Minggu pagi bersamaan dengan adanya pasar mingguan yang juga menyediakan area permainan pada zona 2 , selain itu juga diikuti dengan beberapa komunitas yang juga sering melakukan pertemuan dan koordinasi di area sekitar taman. Jumlah kunjungan yang berbeda atau terjadinya fluktuasi kunjungan ini disebabkan oleh adanya tarikan aktivitas yang ada di Minggu pagi berupa kegiatan pasar mingguan. Tarikan aktivitas ini bertepatan dengan hari libur sehingga sebagian besar pengunjung juga memilih taman sebagai sarana rekreasi dari aktivitas dan rutinitas harian. Invitasi taman juga dipengaruhi oleh kondisi taman yang alami dan rindang sehingga setiap hari selalu dikunjungi sebagai tempat istirahat atau hanya melepas kepenatan di pusat kota.

Tabel 5. Analisis Keberagaman Sarana Permainan dengan Invitasi Pengunjung (Pengamatan Penulis, 2013)

\begin{tabular}{|c|c|c|}
\hline Teori & Eksisting & Temuan Analisis \\
\hline $\begin{array}{l}\text { Ragam permainan yang } \\
\text { disediakan sebaiknya } \\
\text { beragam agar anak-anak } \\
\text { tidak bosan dan memiliki } \\
\text { pilihan untuk bermain, } \\
\text { Walsh dalam Glesson dan } \\
\text { Sipe (2006) }\end{array}$ & $\begin{array}{lr}\text { Ragam } & \text { permainan } \\
\text { sudah cukup beragam } \\
\text { baik pada } & \text { zona } 4 \\
\text { yaitu taman } & \text { bermain } \\
\text { permanen } & \text { maupun } \\
\text { zona } 2 & \text { yang } \\
\text { menyediakan } & \text { area } \\
\text { bermain buatan } & \\
\end{array}$ & $\begin{array}{l}\text { Semakin beragam area permainan yang } \\
\text { disediakan akan semakin menarik minat } \\
\text { pengunjung sehingga terjadi fluktuasi } \\
\text { kunjungan yang berbanding lurus dengan } \\
\text { keragaman sarana permainan. }\end{array}$ \\
\hline $\begin{array}{l}\text { Kesesakan dan kepadatan } \\
\text { adalah keadaan apabila } \\
\text { ruang fisik yang tersedia } \\
\text { sangat } \\
\text { dibandingkan terbatas } \\
\text { jumlah dengan } \\
\text { (Laurens, 2004) }\end{array}$ & $\begin{array}{l}\text { Puncak kunjungan } \\
\text { terjadi pada hari } \\
\text { Minggu pagi karena } \\
\text { ada pasar mingguan, } \\
\text { dan kunjungan } \\
\text { terendah pada setiap } \\
\text { pagi di hari aktif }\end{array}$ & $\begin{array}{l}\text { - Kesesakan atau kepadatan terjadi pada } \\
\text { hari Minggu pagi sebelum jam 9pagi } \\
\text { dimana jumlah pengunjung tidak dapat } \\
\text { ditampung oleh sarana yang tersedia } \\
\text { (kondisi A) }\end{array}$ \\
\hline
\end{tabular}




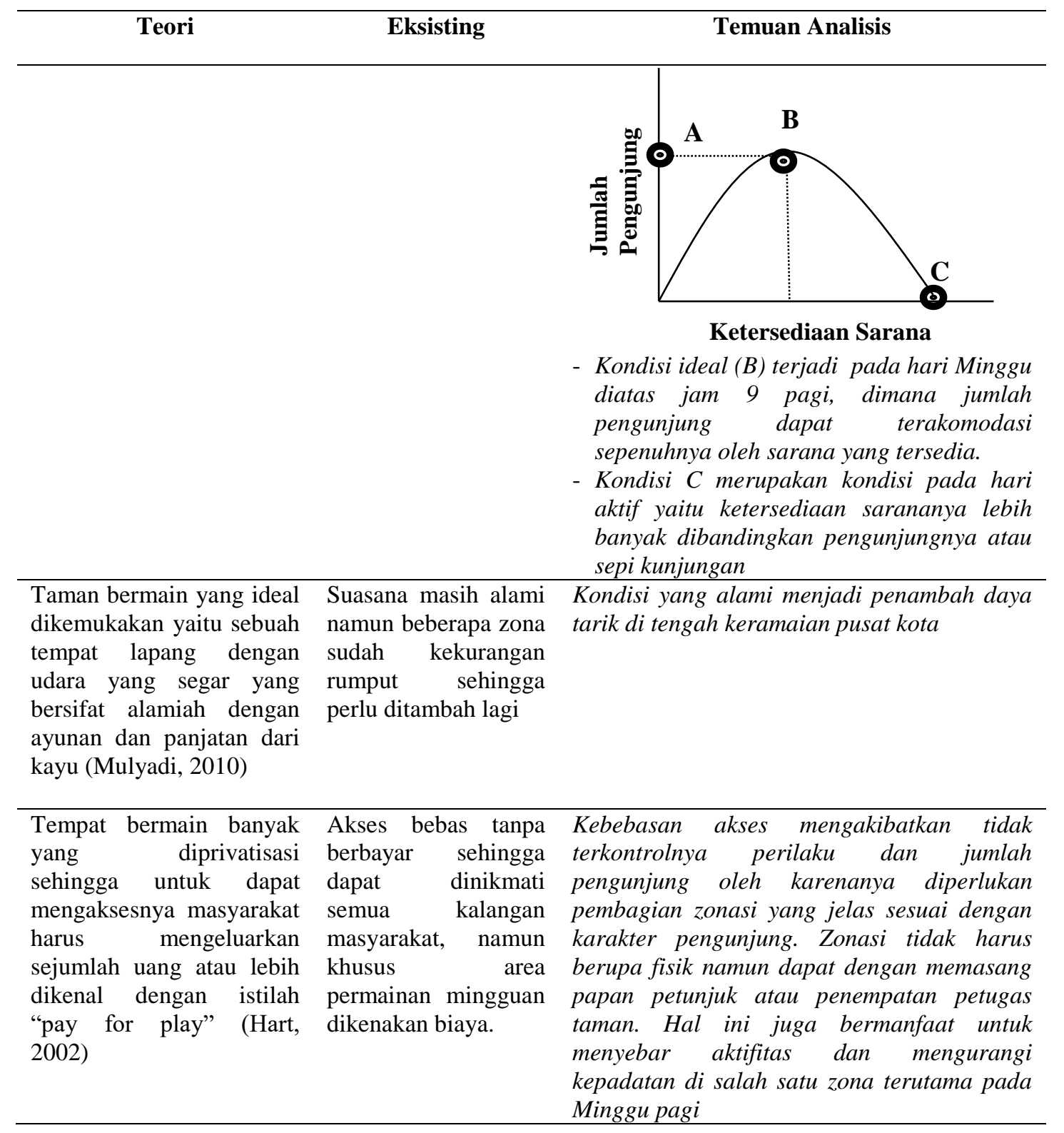

\section{Perlindungan Cuaca}

Karakteristik taman yang ramah anak juga dapat dilihat dengan tersedianya tempat berlindung dari perubahan cuaca baik hujan maupun panas, seperti yang dikemukakan oleh Walsh dalam Glesson dan Sipe (2006). Hal ini dimaksudkan untuk memberikan kenyamanan bagi pengunjung serta sebagai tempat beristirahat. Tempat peneduh ini juga dapat difungsikan sebagai ruang tunggu dan pengawasan orang tua terhadap anak-anaknya yang sedang bermain sehingga orang tua tidak memasuki area permainan anak-anak seperti yang terjadi di taman Menteri Soepeno.

Peneduh atau tempat perlindungan cuaca yang dimaksud adalah yang bersifat free access, sedangkan yang tersedia di taman Menteri Soepeno adalah fasilitas peneduh yang bersifat komersial yang digunakan pedagang untuk berdagang sehingga akses pengunjung terbatas. Fasilitas peneduh yang diperuntukkan bagi pengunjung di dalam area taman belum tersedia, sehingga hal ini perlu untuk ditambahkan karena selain berfungsi untuk melindungi dari perubahan cuaca juga dapat sebagai tempat beristirahat dan menambahkan kenyamanan pengunjung. 


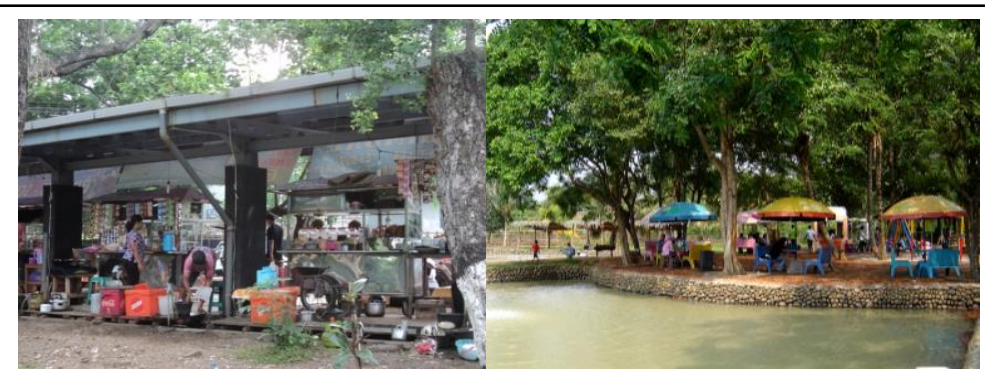

Tidak ada area peneduh di taman Menteri Soepeno, yang tersedia area berkanopi namun diperuntukkan bagi pedagang kaki lima (kiri). Area peneduh dibutuhkan untuk menambah kenyamanan pengunjung dengan perlindungan perubahan cuaca seperti contohnya di Taman Mekarsari (kanan)

Gambar 5. Area Perlindungan Cuaca di Taman Menteri Soepeno (Pengamatan Penyusun, 2013)

Berdasarkan karakteristik yang telah dijabarkan diatas maka dapat disimpulkan bahwa karakteristik taman bermain di taman Menteri Soepeno masih perlu dibenahi untuk dapat menjadikan taman ini ramah anak. Selangkapnya dapat dilihat pada tabel dibawah ini. Hasil penilaian tersebut menunjukkan total nilai yang diperoleh Taman Menteri Soepeno sebagai wadah taman ramah anak sebesar 11, yang berarti taman ini cukup ramah anak, oleh karenanya perbaikan dan pembenahan sangat diperlukan untuk terwujudnya taman yang ramah anak di Taman Menteri Soepeno. Taman Menteri Soepeno telah memiliki wadah sebagai taman ramah anak, namun beberapa hal perlu dibenahi terutama terkait dengan deliniasi atau batasan pengguna dari arena bermain yang telah tersedia. Sebuah ruang terbuka memang memiliki batasan yang kurang jelas, namun sebuah taman tetap harus memiliki segmentasi pengguna yang jelas agar lebih tepat sasaran. Taman bermain di Taman Menteri Soepeno yang baru saja dibangun telah banyak mengalami kerusakan karena tidak adanya batasan pengguna. Semua pengunjung dapat mengakses taman ini dengan leluasa.

Tabel 6. Skor Penilaian Karakteristik Taman Menteri Soepeno (Analisis Penyusun, 2013)

\begin{tabular}{llcc}
\hline \multicolumn{1}{c}{ Variabel } & \multicolumn{1}{c}{ Keterangan } & Skor & Eksisting \\
\hline - Ruang khusus & Tersedia & 3 & $\checkmark$ \\
& Tidak tersedia & 1 & - \\
- Pembatasan Akses & Ada & 3 & - \\
& Tidak & 1 & $\checkmark$ \\
- Ragam permainan & Beragam & 3 & $\checkmark$ \\
- Invitasi & Terbatas & 1 & - \\
& Selalu Menarik & 5 & - \\
& Fluktiatif & 3 & $\checkmark$ \\
- Perlindungan cuaca & Tidak Menarik & 1 & - \\
& Tersedia & 3 & - \\
& Tidak & 1 & $\checkmark$ \\
\hline
\end{tabular}

Berdasarkan analisis yang telah dilakukan sebelumnya menunjukkan bahwa taman Menteri Soepeno ini kurang ramah terhadap anak, beberapa hal perlu dibenahi terkait peningkatan taman ini menjadi ramah anak. Hal yang senada pun juga dirasakan di beberapa taman dan ruang publik ramah anak yang saat ini sudah mulai banyak tersedia. Herlina dan Nadiroh (2018) berpendapat bahwa ketersediaan taman ramah anak sudah banyak sehingga secara jumlah sudah cukup terpenuhi namun secara kualitas masih belum sepenuhnya memenuhi kebutuhan anak. Di kota Semarang pun juga demikian, penyediaan taman pada tiga tahun terakhir ini meningkat dan merata di penjuru kota Semarang yang berdampak kenaikan tingkat kota layak anak dari tingkat pratama ke madya (Prihantini \& Kurniawati, 2018). Hal ini menjadi salah satu bukti bahwa ketersediaan taman ramah anak dapat membantu mewujudkan kota menjadi layak anak. Ketersediaannya menjadi salah satu bukti bahwa kebutuhan anak telah menjadi salah satu prioritas kota ruang terbuka ramah anak merupakan ruang terbuka 
publik, wahana permainan dan tumbuh kembang anak, bagian dari prasarana dan sarana kota layak anak, ruang terbuka hijau, dan sarana kegiatan sosial (Hernowo \& Navastara, 2017). Hal ini penting bagi tumbung kembang anak serta dalam mewujudkan kota menjadi layak anak

\section{Kesimpulan}

Taman Menteri Soepeno sebagai salah satu taman terbesar dan menjadi representasi taman ramah anak ternyata berdasarkan hasil analisis pun berada dalam kategori kurang ramah terhadap anak. Beberapa hal perlu dibenahi terkait peningkatan taman ini menjadi ramah anak. Beberapa temuan yang diharapkan mampu membantu diantaranya telah terjadi celah kebocoran pengguna taman bermain karena tidak tersedianya batasan yang jelas bagi pengunjung taman. Kebebasan akses mengakibatkan tidak terkontrolnya perilaku dan jumlah pengunjung. Kunjungan di taman Menteri Soepeno mengalami fluktuasi yang berbanding lurus dengan keragaman sarana permainan serta kondisi yang alami menjadi penambah daya tarik bagi pengunjung di tengah keramaian pusat kota. Puncak kunjungan terjadi di hari Minggu karena ada aktivitas pasar mingguan sebagai penambah daya tarik dan justru menyebabkan kesesakan atau kepadatan karena jumlah pengunjung tidak dapat ditampung oleh sarana yang tersedia. Berdasarkan temuan tersebut maka diperlukan zonasi untuk memeratakan aktivitas yang ada serta membentuk karakter ruang yang disesuaikan dengan karakteristik pengunjung. Zonasi juga diperlukan untuk mengurangi kebocoran pengguna yang dapat mengurangi fungsi sebuah ruang sehingga taman ini mampu menjadi taman yang ramah anak.

\section{Referensi}

Edney, J. J. (1974). Human territoriality. Psychological Bulletin, 81(12), 959.

Garvin, A., Berens, G., \& Leinberger, C. B. (1997). Urban parks and open space. Urban Land Inst.

Glesson, B., \& Sipe, N. (2006). Creating Child Friendly Cities: Reinstating Kids In The City. London And Newyork: Routledge.

Hart, R. (2002). Containing Children: Some Lessons Planning For Play From New York City. Environment And Urbanization, 14(2), 135-148.

Herlina, N., \& Nadiroh, N. (2018). PERAN STRATEGIS RUANG PUBLIK TERPADU RAMAH ANAK (RPTRA) DALAM RANGKA PEMENUHAN HAK ANAK TERHADAP LINGKUNGAN. JPUD - Jurnal Pendidikan Usia Dini, 12(1), 104-117. https://doi.org/10.21009//JPUD.121.09

Hernowo, E., \& Navastara, A. M. (2017). Karakteristik Ruang Publik Terpadu Ramah Anak (RPTRA) Bahari di Kecamatan Cilandak Jakarta Selatan. Jurnal Teknik ITS, 6(2), C221--C224.

Laurens, J. M. (2004). Arsitektur dan perilaku manusia. Penerbit PT Grasindo.

Lawson, B. (2007). Language of space. Routledge.

Lynch, K. (1960). The image of the city (Vol. 11). MIT press.

Malone, K. (2002). Street life: Youth, culture and competing uses of public space. Environment and urbanization, 14(2), 157-168.

Moss, D. (2010). Memory, space and time: Researching children's lives. Childhood, 17(4), 530-544.

Mulyadi, S. (2010). Kota Dengan Pemenuhan Kebutuhan Anak. Buletin Tata Ruang, 26-27.

Prihantini, P., \& Kurniawati, W. (2018). Availability of Child Friendly Parks for Supporting Child Friendly Cities in Semarang. the 3rd Geoplanning International Conference $n$ Geomatics and Planning, Indonesia. Semarang.

Racelis, M., \& Aguirre, A. D. M. (2002). Child rights for urban poor children in child friendly Philippine cities: views from the community. Environment and Urbanization, 14(2), 97-113.

Reavey, P. (2010). Spatial markings: Memory, agency and child sexual abuse. Memory Studies, 3(4), 314-329.

Riggio, E. (2002). Child friendly cities: good governance in the best interests of the child. Environment and Urbanization, 14(2), 45-58.

Rutledge, A. J. (1981). A visual approach to park design. Wiley-Interscience.

Sarwono, J. (2006). Metode penelitian kuantitatif dan kualitatif. Graha Ilmu.

Sibley, D. (2002). Geographies of exclusion: Society and difference in the West. Routledge.

Sturgess, D. C. (1926). Dwight C. Sturgess to Ida M. Tarbell, January 15, 1926. 